\title{
ANALISIS NITRIT, NITRAT, FOSFAT, DAN ZAT ORGANIK DI SITU-SITU UNIVERSITAS INDONESIA, DEPOK
}

\author{
Siti Mariyam \\ Teknisi Litkayasa pada Loka Riset Pemacuan Stok Ikan, Jatiluhur-Purwakarta
}

Teregristasi I tanggal: 5 April 2006; Diterima setelah perbaikan tanggal: 11 Mei 2006; Disetujui terbit tanggal: 25 Mei 2007

\section{PENDAHULUAN}

Di sekitar kampus Universitas Indonesia terdapat 6 situ dengan luas yang bervariasi dan belum dikelola secara optimal. Situ-situ tersebut dimanfaatkan oleh warga sekitar untuk kegiatan memancing dan menjala ikan serta untuk wisata kampus. Ikan-ikan yang tertangkap antara lain ikan mujair dan sapu-sapu.

Adanya limbah organik dan anorganik yang berasal dari pasar Depok dan hutan kampus menyebabkan ada pencemaran di perairan tersebut sehingga merusak peruntukkan, seperti mengurangi keindahan situ-situ tersebut dan potensi sumber daya ikan yang ada. Untuk pencegahan pencemaran lebih lanjut perlu dilakukan pemantauan kualitas air secara berkala.

\section{BAHAN DAN METODE}

\section{Metode Penelitian}

Monitoring kualitas air ini dilakukan dengan metode survei lapangan dan analisis laboratorium, pengambilan contoh air dengan metode stratified (Nielsen \& Johnson,1985). Pada 2 kedalaman (Situ Kenanga, kedalaman 1 sampai dengan $2 \mathrm{~m}$. Situ Ulin 0 sampai dengan $2 \mathrm{~m}$. Situ Puspa 0 sampai dengan $2 \mathrm{~m}$. Situ Salam 1,0 sampai dengan $1,5 \mathrm{~m}$ dan 0 sampai dengan $2 \mathrm{~m}$ ). Pengambilan contoh 4 situ dengan kedalaman setiap situ 2 kedalaman.

\section{Alat}

1. Kertas saring Whatman ukuran $42 \mu \mathrm{m}$ untuk menyaring contoh air dari lapangan.

2. Corong dari plastik sebagai alat bantu meletakkan kertas saring.

3. Erlenmeyer, wadah untuk menampung contoh air yang sudah di saring.

4. Gelas ukur alat untuk mengambil contoh air.

5. Tabung reaksi, wadah untuk menampung contoh air yang akan ditambah pereaksi.

6. Pipet tetes $10 \mathrm{ml}$, alat untuk menambah pereaksi ke dalam contoh air.

7. Cuvet, wadah untuk menampung contoh air yang akan dibaca konsentrasi.

8. Thermo Spectronic, 20 alat untuk membaca konsetrasi parameter.

\section{Bahan dan Metode Analisis}

\begin{tabular}{|c|c|c|c|}
\hline No. & Parameter & Metode & Pereaksi \\
\hline 1. & $\mathrm{~N}-\mathrm{NO}_{2}$ & Alfa-Naftilamin & $\begin{array}{l}\text { Sulfanilic acid } \\
\text { Alfa-Naftilamin } \\
\text { Na-Acetat }\end{array}$ \\
\hline 2. & $\mathrm{~N}-\mathrm{NO}_{3}$ & Brucine & $\begin{array}{l}\text { Brucine } \\
\mathrm{H}_{2} \mathrm{SO}_{4}\end{array}$ \\
\hline 3. & $\mathrm{P}-\mathrm{PO}_{4}$ & Amonium Molybdate & $\begin{array}{l}\text { Amonium Molybdate } \\
\mathrm{SnCl}\end{array}$ \\
\hline 4. & Bahan oganik total & $\mathrm{KMnO}_{4}$ & $\begin{array}{l}\text { Kalium permanganate } \\
\text { Asam sulfat } \\
\text { Asam Oksalat }\end{array}$ \\
\hline
\end{tabular}

\section{Analisis di Laboratorium}

Cara kerja di laboratorium sebagai berikut:

a. Contoh air yang sudah diambil dari lapangan di saring pakai kertas saring Whatman ukuran 42 $\mu \mathrm{m}$.

b. Ambil contoh air $10 \mathrm{ml}$ menggunakan gelas ukur.

c. Masukkan contoh air tersebut ke dalam tabung reaksi. d. Masukkan contoh air tersebut ke dalam tabung reaksi untuk analisis parameter $\left(\mathrm{N}-\mathrm{NO}_{3}, \mathrm{~N}-\mathrm{NO}_{2}\right.$, dan $\mathrm{P}_{-} \mathrm{PO}_{4}$ ) contoh air sudah dimasukkan ke dalam tabung reaksi di tambah pereaksi yang sesuai dengan yang akan dianalisis.

e. Kemudian contoh air di masukan ke dalam cuvet, selanjutnya untuk mengetahui data akhir besar konsentrasi dibaca dengan menggunakan thermo spectronic. 


\section{HASIL DAN BAHASAN}

Berdasarkan pada hasil-hasil pengamatan dapat disajikan karakteristik situ-situ yang berada di sekitar Kampus Universitas Indonesia pada Tabel 1.

Berdasarkan pada hasil analisis dapat di ketahui bahwa kadar nitrit di beberapa situ berada pada kisaran 0,001 sampai dengan 0,156 mg per I, di banding dengan nilai baku mutu batas ambang 0,06 mg per I, dengan demikian kadar nitrit sudah melebihi ambang batas. Pada data memperlihatkan juga kadar Nitrat berkisaran antara 0,017 sampai dengan 0,116 mg per I dengan nilai baku mutu batas ambang 10 mg per I. Kadar Fosfat juga menunjukkan telah melebihi ambang batas, yaitu pada kisaran 0,072 sampai dengan 0,612 $\mathrm{mg}$ per I dibanding dengan nilai baku mutu batas ambang 0,1 mg per I. Di sisi lain, kandungan zat organik menunjukkan pada kisaran 2,97 sampai dengan 7,64 mg per I dibanding dengan nilai baku mutu batas ambang $10 \mathrm{mg}$ per $\mathrm{l}$.

Hasil analisis contoh di laboratorium, dapat diketahui nilai-nilai nitrit, nitrat, fospat, dan organik yang terlarut di perairan situ-situ sekitar Kampus Universitas Indonesia, yang disajikan pada Tabel 2.

Tabel 1. Karakteristik situ-situ di sekitar Kampus Universitas Indonesia, Depok

\begin{tabular}{cccll}
\hline No. & Nama situ & \multicolumn{1}{c}{ Luas } & \multicolumn{1}{c}{ Deskripsi } & \multicolumn{1}{c}{ Lokasi } \\
\hline 1. & Situ Kenanga & 4.379 ha $\left(43785,413894 \mathrm{~m}^{2}\right)$ & $\begin{array}{l}\text { Warna air hijau } \\
\text { kehitaman }\end{array}$ & $\begin{array}{l}\text { Di dekat Mesjid } \\
\text { Universitas Indonesia } \\
\text { dan kantor Rektorat }\end{array}$ \\
2. & Situ Ulin & 4,967 ha $\left(49674,7708531 \mathrm{~m}^{2}\right)$ & $\begin{array}{l}\text { Warna air keruh } \\
\text { hijau kecoklatan }\end{array}$ & $\begin{array}{l}\text { Di belakang Fakultas } \\
\text { Ekonomi }\end{array}$ \\
3. & Situ Puspa & 1.906 ha $\left(19055,802721 \mathrm{~m}^{2}\right)$ & $\begin{array}{l}\text { Warna air hujau } \\
\text { kehitaman }\end{array}$ & $\begin{array}{l}\text { Di dekat Fakultas } \\
\text { Ekonomi Universitas } \\
\text { Indonesia }\end{array}$ \\
4. & Situ Salam & 5,262 ha $\left(52621,886194 \mathrm{~m}^{2}\right)$ & Warna air & $\begin{array}{l}\text { Di Komplek Cagar } \\
\text { Kuah }\end{array}$ \\
5. & Situ Mahoni & $5.137 \mathrm{ha}\left(51373,174262 \mathrm{~m}^{2}\right)$ & - & - \\
6. & Situ Agathia & 3.057 ha $\left(39565,860531 \mathrm{~m}^{2}\right)$ & - & - \\
\hline
\end{tabular}

Tabel 2.

Nilai beberapa parameter kimia di perairan situ-situ sekitar Kampus Universitas Indonesia, Depok

\begin{tabular}{|c|c|c|c|c|c|c|c|c|c|c|c|c|}
\hline \multirow{4}{*}{ No. } & \multirow{4}{*}{ Parameter } & \multicolumn{10}{|c|}{ Stasion } & \multirow{4}{*}{$\begin{array}{l}\text { Baku } \\
\text { Mutu }\end{array}$} \\
\hline & & \multirow{2}{*}{\multicolumn{2}{|c|}{$\begin{array}{c}\text { Situ Kenanga } \\
\text { Kedalaman }\end{array}$}} & \multirow{2}{*}{\multicolumn{2}{|c|}{$\frac{\text { Situ Ulin }}{\text { Kedalaman }}$}} & \multirow{2}{*}{\multicolumn{2}{|c|}{$\begin{array}{l}\text { Situ Puspa } \\
\text { Kedalaman }\end{array}$}} & \multicolumn{4}{|c|}{ Situ Salam } & \\
\hline & & & & & & & & \multicolumn{4}{|c|}{ Kedalaman } & \\
\hline & & 0 & 1 & 0 & 2 & 0 & 2 & 0 & 1,5 & 0 & 2 & \\
\hline 1. & $\mathrm{~N}-\mathrm{NO}_{2}(\mathrm{mg} / \mathrm{L})$ & 0,156 & 0,137 & 0,098 & 0,117 & 0,137 & 0,059 & 0,098 & 0,001 & 0,02 & 0,039 & 0,06 \\
\hline 2. & $\mathrm{NNO}_{3}(\mathrm{mg} / \mathrm{L})$ & 0,097 & 0,087 & 0,057 & 0,116 & 0,077 & 0,057 & 0,047 & 0,017 & 0,027 & 0,057 & 10 \\
\hline 3. & $\mathrm{P}-\mathrm{PO}_{4}(\mathrm{mg} / \mathrm{L})$ & 0,73 & 0,432 & 0,432 & 0,072 & 0,612 & 0,072 & 0,432 & 0,972 & 0,732 & 0,612 & $0,1^{*}$ \\
\hline 4. & $\begin{array}{l}\text { Zat Organik } \\
(\mathrm{mg} / \mathrm{L})\end{array}$ & 5,94 & 7,07 & 5,37 & 4,23 & 7,64 & 8,21 & 2,97 & 5,94 & 4,23 & 4,8 & $10^{*}$ \\
\hline
\end{tabular}

\section{KESIMPULAN}

1. Konsentrasi nitrit dan fospat, di perairan situ-situ sekitar Kampus Universitas Indonesia, Depok sudah melebihi batas ambang baku mutu untuk biota.

2. Sedangkan nitrat dan zat organik memenuhi ambang baku mutu untuk biota.

\section{DAFTAR PUSTAKA}

Haryadi, S., Suryadiputra, I. N. N., \& Widigdo, B. 1990. Limnologi metode analisa kualitas air. Institut Pertanian Bogor. Bogor.

Nielsen \& Jonhson. 1985 Fisheries technigues. American Fisheris Society Bethesda Maryland. 
Lampiran 1. Peta lokasi situ-situ di sekitar Kampus Universitas Indonesia, Depok

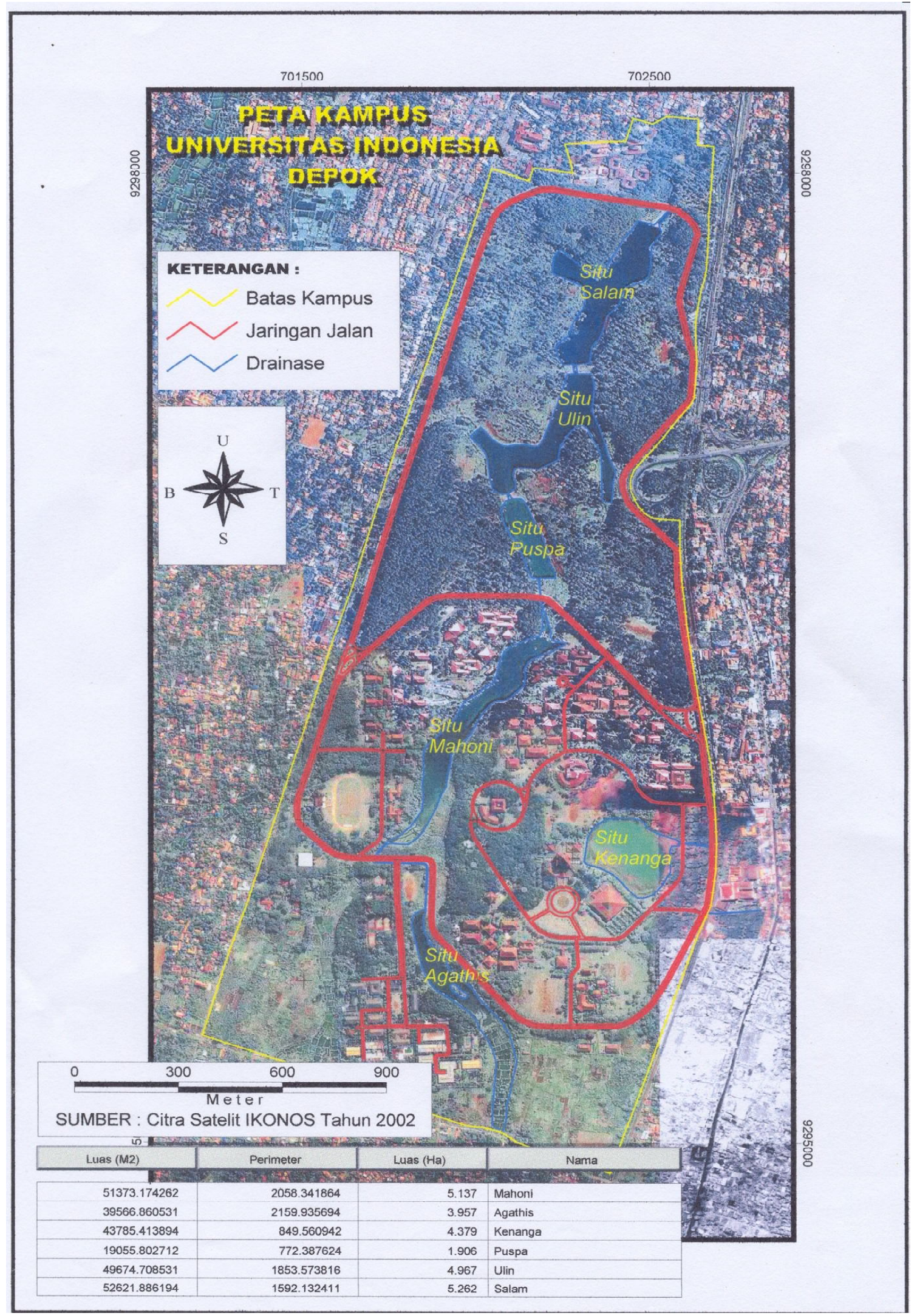

